\title{
RECORDS OF THE GLOBALLY THREATENED RUSTY-SPOTTED CAT IN ODISHA, INDIA
}

\author{
Himanshu S. Palei ${ }^{1, *}$, Nimain C. Palei ${ }^{2}$, Bhakta P. Rath ${ }^{2}$, Arun K. Mishra ${ }^{3}$ \\ ${ }^{1}$ North Orissa University, India \\ ${ }^{2}$ Office of the PCCF (Wildlife) and Chief Wildlife Warden, India \\ ${ }^{3}$ Sundargarh Forest Division, India \\ *e-mail: himanshu.palei@gmail.com
}

Received: 22.04.2019. Revised: 12.07.2019. Accepted: 13.07.2019.

\begin{abstract}
The Rusty-spotted Cat, Prionailurus rubiginosus, is a vulnerable species, endemic to India, Nepal and Sri Lanka. The goal of the study is to provide an overview of the current distribution of the Rusty-spotted Cat in Odisha state through camera trap survey, review of published scientific literature and rescue records. This study presents 14 localities including seven new localities from the Odisha state in India. A long-term study, habitat protection and studying its ecology are recommended for initiating further steps to conserve its range.
\end{abstract}

Key words: camera traps, conservation, distribution range, Prionailurus rubiginosus, small cats, threats

\section{Introduction}

The Rusty-spotted Cat Prionailurus rubiginosus (I. Geoffroy Saint-Hilaire, 1831) is the smallest feline in the world and endemic to India, Nepal and Sri Lanka (Mukherjee et al., 2016). It has been predicted that the global population may decline by $20-25 \%$ in the coming decades corresponding to a loss and degradation of the remaining habitat (Mukherjee et al., 2016). The preferred habitat for this species is associated with dense vegetation in moist and dry deciduous forest as well as scrub and grassland (Patel, 2011). Further, there are also reports of its occurrence within agricultural areas and human settlements (Nowell \& Jackson, 1996; Mukherjee, 1998; Nekaris, 2003; Athreya, 2010). The Rusty-spotted Cat's status, distribution and ecology are still unknown because of its elusive behaviour and naturally low density (Mukherjee et al., 2016).

This species is affected by habitat loss and $75 \%$ of its habitat in the current distributional range facing an imminent danger of conversion of forest to agriculture and industry (Mukherjee et al., 2016). According to the International Union for Conservation of Nature (IUCN), the Rusty-spotted Cat is now listed in the «Near Threatened» category because of its larger range than previously known. It is protected under the Schedule I of the Indian Wildlife (Protection) Act, 1972. However, a lack of systematic surveys on its status has designated it as one of the lesser known species throughout its distributional range (Mukherjee et al., 2016).
In India, this species is found in an irregular manner from the extreme south of Tamil Nadu to the extreme north of Jammu and Kashmir and from the extreme west of Gujarat to Odisha (formerly known as Orissa) in the east, through Madhya Pradesh in the central region (Patel \& Jackson, 2005; Mali \& Srinivasulu, 2015; Nayak et al., 2017). Although the Rusty-spotted Cat's distribution covers the large part of Odisha, eastern India, there are few records in this state (Palei \& Debata, 2019). This may be due to the ecological feature of the species, such as naturally low density and secretive behaviour (Mukherjee et al., 2016), but probably reflect the lack targeted surveys by biologists which is evident from the recent faunal inventories (Mohapatra et al., 2014; Debata et al., 2013; Debata et al., 2015; Palei H. et al., 2018). Here we present a review of the occurrence and current distribution range of the Rusty-spotted Cat and also add some distribution records from Odisha, eastern India.

\section{Material and Methods}

Odisha State is located between 17.49 $22.34^{\circ} \mathrm{N}$ and $81.29-87.29^{\circ} \mathrm{E}$ covering an area of $155707 \mathrm{~km}^{2}$ along the eastern coast of India (Fig. 1). Odisha falls under the Deccan Peninsula biogeographic zone spreading over the Deccan plateau, the Central highlands, the Eastern Ghats, the Gangetic plain and Coasts biogeographic province (Sinha, 1971). Most precipitation falls during the monsoon, with a mean annual total rainfall of 1451 $\mathrm{mm}$. Temperatures range from a minimum of $2^{\circ} \mathrm{C}$ in winter to a maximum of $45^{\circ} \mathrm{C}$ in summer. 


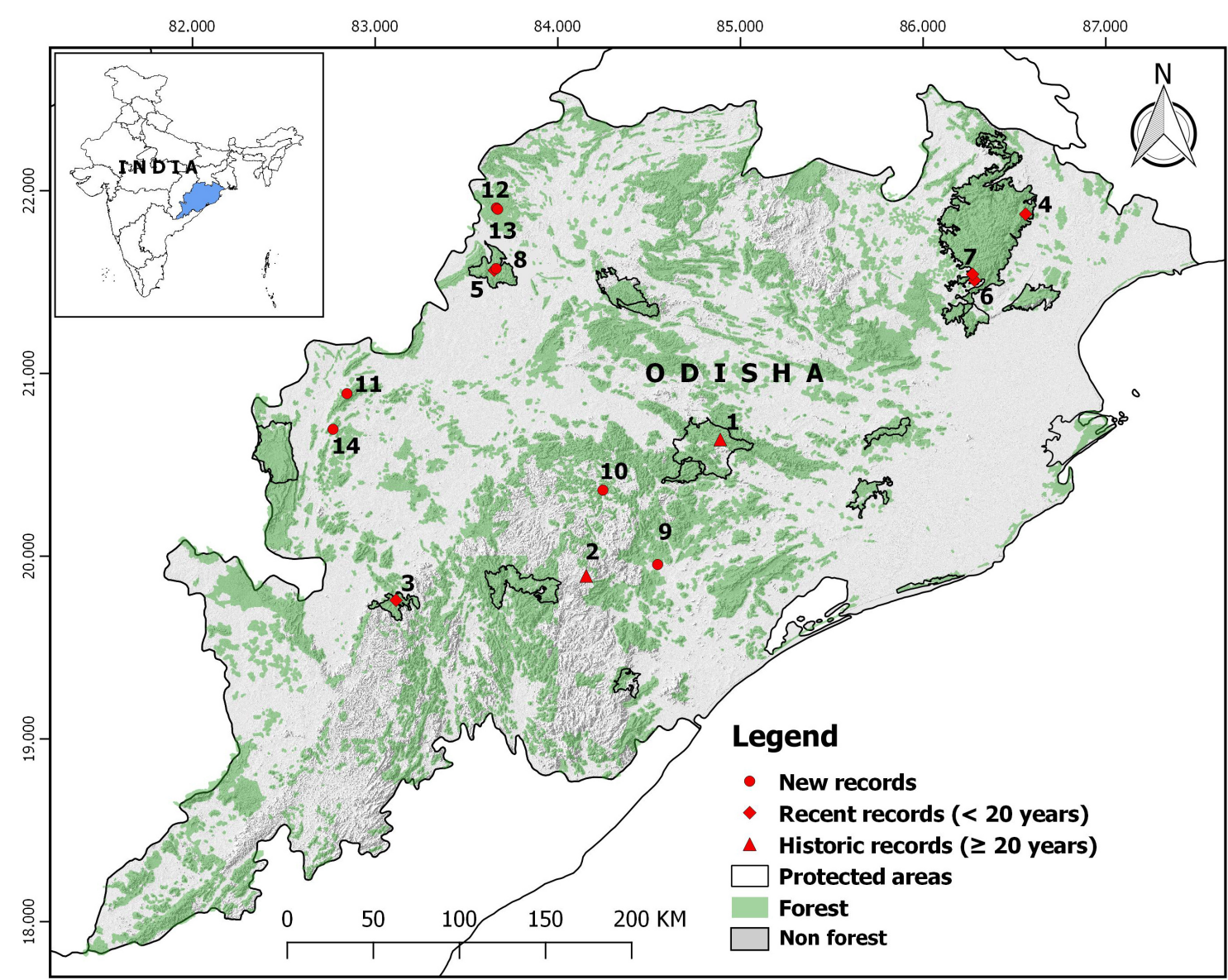

Fig. 1. Map showing the locations of the Rusty-spotted Cat Prionailurus rubiginosus occurrence in Odisha, eastern India.

To assess the current distribution status of the Rusty-spotted Cat in Odisha, we reviewed available literature including published articles, books and unpublished reports. We also gathered records from forest department rescues and camera trap surveys conducted in different part of Odisha. Camera traps were deployed in forest patches in seven forest divisions and seven wildlife sanctuaries (Table 1). The study was carried out for terrestrial mammals from January 2017 to December 2018 in Odisha (Palei N. et al., 2018). Camera traps were installed at 493 sampling stations in forest plains to hilly terrain along the animal trails, nullahs as well as rocky and sandy stream beds (Table 1). Each camera trap station was composed of two camera traps (Cuddeback Model C1). All camera traps were strapped to trees approximately $40 \mathrm{~cm}$ above ground. Camera traps were set to operate $24 \mathrm{~h}$ per day and programmed to delay sequential photographs by $30 \mathrm{~s}$ recording time. Each camera trap was checked at least once a week for battery level, positioning and to replace memory (SD) cards. Each photograph was manually checked to identify the species. Date, time and temperature were noted for each identified species.

\section{Results and Discussion}

During the survey we recorded a total of 14 localities, including seven published records, two rescue records and five camera trap records (Table 2, Fig. 1, Fig. 2). Out of these 14 localities, seven localities were in Protected Areas (Fig. 1). The Rusty-spotted Cat was previously known from seven localities. So, in this study, we recorded seven more localities of this species from different parts of Odisha (Fig. 2). All these new localities were recorded between 2016 and 2018. The total sampling had 493 camera-trap stations, with a total sampling effort of 12325 trap days, considering all camera-trap stations (Table 1). We obtained five Rusty-spotted Cat photos in different camera trap stations (Table 1, Table 2).

As mentioned in Material and Methods, camera traps were deployed to gather information on terrestrial mammals and was not species-specific. As a result, these camera traps were installed at a height of $40 \mathrm{~cm}$ above ground. There are possibilities of missing out small carnivore species like the Rustyspotted Cat. The detection probability of the Rustyspotted Cat might be different and hence there may be a difference between estimated photo captured and actual captured in Table 1. 
Table 1. Summary of camera trap capture records of Rusty-spotted Cat Prionailurus rubiginosus in different forest divisions, Odisha, India

\begin{tabular}{|c|l|c|c|c|c|}
\hline No. & \multicolumn{1}{|c|}{ Name of forest division } & Camera trap stations & Trap days & Total sampling effort & Rusty-spotted Cat photo captured \\
\hline 1 & Sundargarh Forest Division & 45 & 25 & 1125 & 2 \\
\hline 2 & Debrigarh Wildlife Sanctuary & 39 & 25 & 975 & 1 \\
\hline 3 & Baragarh Forest Division & 45 & 25 & 1125 & 1 \\
\hline 4 & Balangir Forest Division & 37 & 25 & 925 & 0 \\
\hline 5 & Sunabeda Wildlife Sanctuary & 35 & 25 & 875 & 0 \\
\hline 6 & Hadagarh Wildlife Sanctuary & 40 & 25 & 1000 & 1 \\
\hline 7 & Kuldiha Wildlife Sanctuary & 40 & 25 & 1000 & 0 \\
\hline 8 & Karlapat Wildlife Sanctuary & 34 & 25 & 850 & 0 \\
\hline 9 & Kalahandi North Forest Division & 21 & 25 & 525 & 0 \\
\hline 10 & Rourkela Forest Division & 33 & 25 & 825 & 0 \\
\hline 11 & Bonai Forest Division & 35 & 25 & 875 & 0 \\
\hline 12 & Khariar Forest Division & 38 & 25 & 950 & 0 \\
\hline 13 & Khalasuni Wildlife Sanctuary & 26 & 25 & 650 & 0 \\
\hline 14 & Badrama Wildlife Sanctuary & 25 & 25 & 625 & \\
\hline Total & & 493 & 25 & 12325 & \\
\hline
\end{tabular}
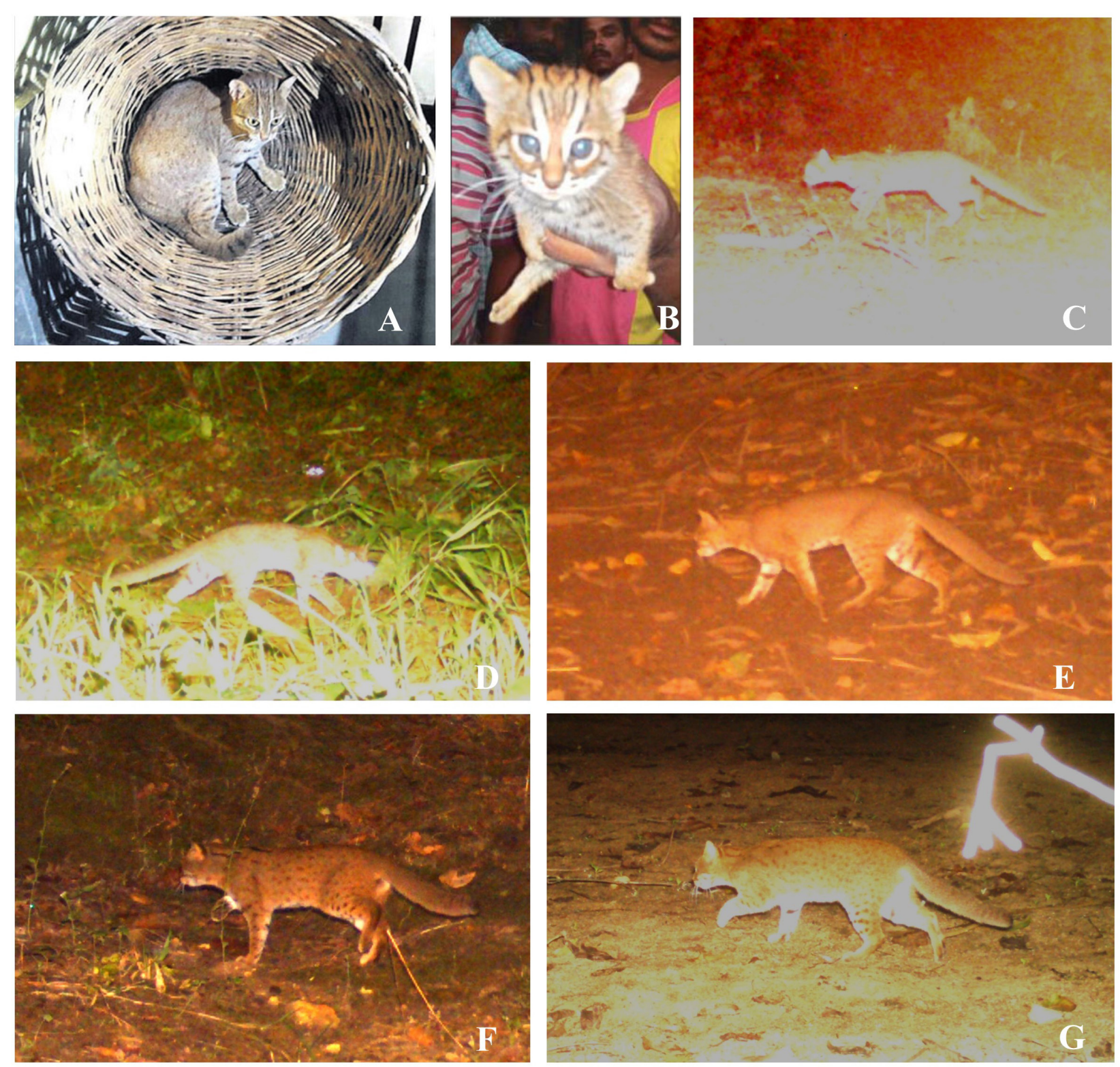

Fig. 2. Occurrence records of the Rusty-spotted Cat Prionailurus rubiginosus in Odisha, eastern India. A. Rescued in Ghumusur North Forest Division; B. Rescued in Phulbani Forest Division; C. Camera trapped in Debrigarh Wildlife Sanctuary; D. Camera trapped in Bargarh Forest Division; E. Camera trapped in Sundargarh Forest Division; F. Camera trapped in Sundargarh Forest Division; G. Camera trapped in Bolangir Forest Division (see details in Table 2). 
Table 2. All available records on the occurrence of the Rusty-spotted Cat Prionailurus rubiginosus in Odisha, India (numbers of locations correspond with numbers in Fig. 1)

\begin{tabular}{|c|c|c|c|c|c|}
\hline No. & Year & Locations & Forest type & $\begin{array}{l}\text { Type of } \\
\text { records }\end{array}$ & Sources \\
\hline 1 & 1969 & $\begin{array}{l}\text { Tuluka Reserve Forest near Purunakote village of Satkosia Tiger } \\
\text { Reserve, Satkosia Wildlife Division, Angul District }\end{array}$ & Moist deciduous forest & $\begin{array}{l}\text { Published } \\
\text { records }\end{array}$ & Write, 1984 \\
\hline 2 & 1995 & $\begin{array}{l}\text { Bhramaramadi village near Daringibadi of Baliguda Forest } \\
\text { Division, Phulabani District }\end{array}$ & Moist deciduous forest & $\begin{array}{l}\text { Published } \\
\text { records }\end{array}$ & Acharjyo et al., 1997 \\
\hline 3 & 2010 & $\begin{array}{l}\text { Karlapat Wildlife Sanctuary of Kalahandi South Wildlife } \\
\text { Division, Kalahandi District }\end{array}$ & Dry deciduous forest & $\begin{array}{l}\text { Published } \\
\text { records }\end{array}$ & Palei \& Debata, 2019 \\
\hline 4 & 2013 & $\begin{array}{l}\text { Chandanpur village near Dukura range of Similipal Tiger } \\
\text { Reserve, Baripada Forest Division, Mayurbhanj District }\end{array}$ & Moist deciduous forest & $\begin{array}{l}\text { Published } \\
\text { records }\end{array}$ & Palei \& Debata, 2019 \\
\hline 5 & 2014 & $\begin{array}{l}\text { On a forest road leading to Jhagadabehera village of Lakhanpur } \\
\text { range, Hirakud Wildlife Division, Sambalpur District }\end{array}$ & Dry deciduous forest & $\begin{array}{l}\text { Published } \\
\text { records }\end{array}$ & Palei \& Debata, 2019 \\
\hline 6 & 2017 & $\begin{array}{l}\text { Dangadiha beat, Kaptipada range, Similipal Tiger Reserve, } \\
\text { Baripada Forest Division, Mayurbhanj District }\end{array}$ & Moist deciduous forest & $\begin{array}{l}\text { Published } \\
\text { records }\end{array}$ & Mishra et al., 2019 \\
\hline 7 & 2017 & $\begin{array}{l}\text { Dangadiha beat, Kaptipada range, Similipal Tiger Reserve, } \\
\text { Baripada Forest Division, Mayurbhanj District }\end{array}$ & Moist deciduous forest & $\begin{array}{l}\text { Published } \\
\text { records }\end{array}$ & Mishra et al., 2019 \\
\hline 8 & 2017 & $\begin{array}{l}\text { Jhagadabehera village of Lakhanpur range, Debrigarh Wildlife } \\
\text { Sanctuary, Hirakud Wildlife Division, Sambalpur District }\end{array}$ & Dry deciduous forest & Camera trap & Present study \\
\hline 9 & 2017 & $\begin{array}{l}\text { Binjigiri, Bhanjanagar, Ghumusur North Forest Division, } \\
\text { Ganjam District }\end{array}$ & Moist deciduous forest & Rescued & Present study \\
\hline 10 & 2018 & Keredi, Suradei, Phulbani Forest Division, Phulbani District & Moist deciduous forest & Rescued & Present study \\
\hline 11 & 2018 & $\begin{array}{l}\text { Jamseth, Gandhmardhan Proposed Reserve Forest, Nrusinghanath } \\
\text { range of Bargarh Forest Division, Bargarh District }\end{array}$ & Dry deciduous forest & Camera trap & Present study \\
\hline 12 & 2018 & $\begin{array}{l}\text { Dangakhol, Garjanpahad Reserve Forest, Dagora, Hemgiri, } \\
\text { Sundargarh Forest Division, Sundargarh District }\end{array}$ & Dry deciduous forest & Camera trap & Present study \\
\hline 13 & 2018 & $\begin{array}{l}\text { Telianala of Chengapahad, Kanika, Hemgiri Reserve Forest, } \\
\text { Sundargarh Forest Division, Sundargarh District }\end{array}$ & Dry deciduous forest & Camera trap & Present study \\
\hline 14 & 2018 & Jhaliati, Lathore, Bolangir Forest Division, Bolangir District & Dry deciduous forest & Camera trap & Present study \\
\hline
\end{tabular}

The Rusty-spotted Cat is relatively rare in comparison to other small cats found in Odisha (Palei et al., 2016; Palei H. et al., 2018; Palei \& Debata, 2019). However, it is found to be widespread in Odisha. The population of the Rusty-spotted Cat is threatened from human induced activities mainly conversion of forest habitat for development. The last seven decades $40.5 \%$ of the forest cover was declined in Odisha (Reddy et al., 2013). Deforestation started mainly after the development of infrastructure, dam construction and intense population growth after country's independence (Reddy et al., 2013).

For effective conservation and management of globally threatened species, information on the population status, movement patterns, diet, habitat requirements and demography as well as population status and ecology of prey species is required(Grassman et al., 2005). Unlike to other congeners, little is known about the natural history and population status of the Rusty-spotted Cat. Similar to our study, most of the data on the Rusty-spotted Cat are available mainly from opportunistic sightings and bycatch camera trap images from large carnivore study (Mukherjee et al., 2016). No studies have been targeted on the Rustyspotted Cat in its range. Therefore, its population status and identification of known and possible threats for this cat are highly recommended.

The recent increase in occurrence of the Rustyspotted Cat from different locations in Odisha and elsewhere in India is of concern and necessitates awareness raising programmes, particularly for locals and forest departments who occasionally misidentified the animal with the Jungle Cat Felis chaus Schreber, 1777 and leopard cub Panthera pardus (Linnaeus, 1758) (Palei \& Debata, 2019). The lack of scientific understanding of the Rusty-spotted Cat in Odisha and elsewhere in its range restricts the ability to conserve the species. Identification and conservation of the Rustyspotted Cat key habitats can play an important role in conservation planning for the species. Therefore, we recommend to conduct a large-scale habitat modelling study for a better understanding of its potential distribution range, not only within the Odisha state, but broader, in its total distributional range.

\section{Acknowledgements}

We are grateful to Dr. Sandeep Tripathi (Principal Chief Conservator of Forests (Wildlife) and Chief Wildlife Warden, Odisha Forest Department) for supporting and granting us permission to carry out the study. We are thankful to Divisional Forest Officers and all forest officials for supporting the study. 


\section{References}

Acharjyo L.N., Purohit K.L., Patnaik S.K. 1997. Occurrence of the Rusty-spotted Cat in Orissa. Journal of Bombay Natural History Society 94: 554-555.

Athreya V. 2010. Rusty-spotted Cat more common than we think? Cat News 53: 27.

Debata S., Palei H.S., Mohapatra P.P., Palita S.K. 2015. Additional Records of Cantor's Leaf-Nosed Bat Hipposideros galeritus Cantor, 1846 (Mammalia: Chiroptera: Hipposideridae) in Eastern India: Odisha. Journal of Threatened Taxa 7(8): 7477-7479. DOI: 10.11609/JoTT.o4247.7477-9

Debata S., Palei H.S., Mohapatra P.P., Mishra A.K. 2013. First record of Lesser False Vampire Bat (Megaderma spasma, Linnaeus, 1758) from Sundargarh, Odisha, India. Small Mammal Mail 5(1): 26-27.

Grassman Jr. L.I., Tewes M.E., Silvy N.J., Kreetiyutanont K.J. 2005. Ecology of three sympatric felids in a mixed evergreen forest in north-central Thailand. Journal of Mammology 86(1): 29-38. DOI: 10.1644/1545-1542(2005)086<0029:EOTSFI $>2.0 . C O ; 2$

Mali S., Srinivasulu C. 2015. Records of Rusty-Spotted Cat, Sri Lankamalleshwara Wildlife Sanctuary India. Cat News 62: 20-21.

Mishra S.R., Mohan M., Pati J. 2019. Camera trap records of rusty-spotted cat from Similipal Tiger Reserve, Odisha, India. Cat News 69: 26-27.

Mohapatra P.P., Palei H.S., Hussain S.A. 2014. Occurrence of Asian Small-Clawed Otter Aonyx cinereus (Illiger, 1815) in Eastern India. Current Science 107(3): 367-370.

Mukherjee S. 1998. Cats: some large many small. In: S.K. Mukherjee (Ed.): Small Cats of India. Envis Bulletin. Vol. 1(1). Dehradum: Wildlife Institute of India. P. 5-13.

Mukherjee S., Duckworth J.W., Silva A., Appel A., Kittle A. 2016. Prionailurus rubiginosus. In: The IUCN Red List of Threatened Species 2016: e.T18149A50662471. Available from http://dx.doi.org/10.2305/IUCN. UK.2016-1.RLTS.T18149A50662471.en

Nayak S., Shah S., Borah J. 2017. First record of Rustyspotted Cat Prionailurus rubiginosus (Mammalia:
Carnivora: Felidae) from Ramgarh-Vishdhari Wildlife Sanctuary in semi-arid landscape of Rajasthan, India. Journal of Threatened Taxa 9(1): 9761-9763. DOI: 10.11609/jott.3303.9.1.9761-9763

Nekaris K.A.I. 2003. Distribution and behaviour of three small wild cats in Sri Lanka. Cat News 38: 30-32.

Nowell K., Jackson P. 1996. Wild Cats: Status Survey and Conservation Action Plan. Gland, Switzerland: IUCN. 383 p.

Palei H.S., Debata S. 2019. On the Occurrence of RustySpotted Cat Prionailurus rubiginosus (I. Geoffroy SaintHilaire, 1831) (Mammalia: Carnivora: Felidae) in Odisha, Eastern India. Proceedings of the Zoological Society 72(1): 102-105. DOI: 10.1007/s12595-017-0243-x

Palei H.S., Das U.P., Debata S. 2018. The vulnerable fishing cat Prionailurus viverrinusin Odisha, eastern India: status and conservation implications. Zoology and Ecology 28(2): 69-74. DOI: 10.1080/21658005.2018.1468646

Palei H.S., Pradhan T., Sahu H.K., Nayak A.K. 2016. Estimating mammalian abundance using camera traps in the tropical forest of Similipal Tiger Reserve, Odisha, India. Proceedings of the Zoological Society 69(2): 181-188. DOI: 10.1007/s12595-015-0143-x

Palei N.C., Rath B.P., Palei H.S., Mishra A.K. 2018. Occurrence of melanistic leopard in Odisha, eastern India. Cat News 68: 7-8.

Patel K. 2011. Preliminary survey of small cats in Eastern Gujarat, India. Cat News 54: 8-11.

Patel K., Jackson P. 2005. Rusty-spotted cat in India: new distribution data. Cat News 42: 27.

Reddy C.S., Jha C.S., Dadhwal V.K. 2013. Assessment and monitoring of long-term forest cover changes in Odisha, India using remote sensing and GIS. Environmental Monitoring and Assessment 185(5): 4399-4415. DOI: 10.1007/s10661-012-2877-5

Sinha B.N. 1971. Geography of Orissa. New Delhi: National Book Trust. 172 p.

Wright A. 1984. A note on the wild cats of the north-eastern region of India. In: P. Jackson (Ed.): The plight of the cats. Madhya Pradesh: IUCN/SSC Cat Specialist Group. P. 81-84.

\title{
НАХОДКИ ГЛОБАЛЬНО УГРОЖАЕМОГО ВИДА РЖАВОЙ КОШКИ В ОДИШЕ (ИНДИЯ)
}

\author{
Х. С. Палей ${ }^{1, *}$ Н. Ч. Палей ${ }^{2}$, Б. П. Рат ${ }^{2}$, А. К. Мишра ${ }^{3}$ \\ ${ }^{1}$ Университет Северной Ориссы, Индия

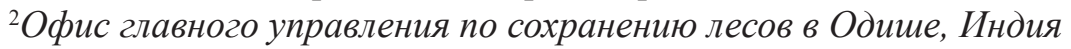 \\ $\sqrt[3]{Л е с н о и ̆ ~ о т д е л ~ в ~ С у н д а р г а р х е, ~ И н д и я ~}$ \\ *e-mail: himanshu.palei@gmail.com
}

\begin{abstract}
Ржавая кошка, Prionailurus rubiginosus, является уязвимым видом, эндемиком для Индии, Непала и Шри Ланки. Целью исследования явилось представить обзор современного распространения ржавой кошки в штате Одиша (Индия) с использованием данных фотоловушек, литературы, и находок спасенных животных. Данное исследование представляет 14 местонахождений, включая семь новых для штата Одиша. Долговременное изучение, охрана местообитаний и экологии вида необходимы для осуществления следующих шагов по сохранению ржавой кошки на этой территории.
\end{abstract}

Ключевые слова: Prionailurus rubiginosus, ареал, малые кошки, сохранение, угрозы, фотоловушки 